\title{
LII. On the measurement (by Trigonometry) of the heights of the principal Hills of Wensleydale, Yorkshire
}

\section{John Nixon Esq.}

To cite this article: John Nixon Esq. (1829) LII. On the measurement (by Trigonometry) of the heights of the principal Hills of Wensleydale, Yorkshire, Philosophical Magazine Series 2, 5:29, 350-362, DOI: $10.1080 / 14786442908675016$

To link to this article: http://dx.doi.org/10.1080/14786442908675016

册 Published online: 10 Jul 2009.

Submit your article to this journal $[\pi$ 
tainly not the coal itself, but the outburst of a bed of such argillaceous schist as invariably accompanies coal-beds, mixed with a few small pieces of coal, probably proceeding from the outburst or crop of a seam within a very short distance of the spot. So strong indeed are the indications of coal at this place, that of its existence in the immediate vicinity I have not the slightest doubt. Of its qualities, thickness, \&c., of course no idea can be formed without boring; but there is every reason to'suppose that the same beds will be found here as those which are at present sinking to at Whitwick and Ibstock.

Note.-From the hasty manner in which this survey was made, I had no opportunity of taking elevations; but it is extremely probable that the outbreak of the coal-measures through the new red sandstone near Birstall is conuected with the elevation of the ground. Near Ashby also I observed the like appearance under similar circumstances, where, although the low grounds are occupied by the deposit of new red sandstone, yet on the top of a hill a bed of siliceous sandstone, evidently belonging to the coal-measures, protrudes itself to the surface, and is quarried for the purposes of building.

F.F.

LII. On the Measurement (by Trigonometry) of the Heights of the principal Hills of Wensleydale, Yorkshire. By JонN Nixon, Esq.*

EARLY in June last I commenced the above undertaking, and succeeded, notwithstanding the extremely unfavour: able state of the weather, in completing the requisite measurements by the middle of July. With a view to increase the accuracy of the survey, the third or verification angles of some of the principal triangles were, however, obtained in September, at Ingleborough and Whernside; and in November, at Shunnor Fell : yet so unsatisfactory, in consiequence of the continued haziness of the atmosphere, were the observations, as to render it doubtful whether it would not have been preferable to have rejected them.

In the selection of the hills, the transverse and lateral (or boundary) ridges, of which Wensleydale entirely consists, were surveyed; and the principal passes (or extreme depressions of the ridges) being ascertained, the loftiest point of ground comprehended between every two adjacent passes was carefully determined and marked for measurement. At the head of the dale, several of the transverse ridges, diverging with a gradual descent from one common crest, terminate in lofty and steep head-lands, or knabs. As no part of hills of this description could with propriety be designated the summit, the measurement of the height of any other point was not attempted.

- Communicated by the Author. 
On commencing the survey, it was discovered that the twelveinch telescopic-level, recently fitted up with extremely fine cross-wires, would not, from some imperfection in the screws of the stop, retain its adjustments. The extreme summit of the hill was, therefore, of necessity estimated by the eye alone previous to the erection of the signal. That no material error had been committed in the few doubtful cases which occurred, was subsequently confirmed; not only where the theodolite was erected, from actual levelling around the signal by means of that instrument, but also by remarking in the course of the observations that the horizontal wire of the telescope, when pointed at the base of the signal on any of the distant hills of about the same altitude as the station, did not dip sensibly below any other part of that hill. The signal on Bakestone Edge was found to be rather lower than a point more to the north; but the latter was evidently within the boundary of Swaledale, and consequently out of the limits of the survey. Viewed from the signal on the Stake Fell, a peat hillock nearly two miles to the south-east was suspected to be quite as high; but it was noted, on repairing there, that a straight line drawn from the hillock through the base of the signal, would touch a point of Water Crag very little below the level of its summit. Now as Water Crag has been determined to be about 350 feet higher than Stake Fell, it proves that the signal was placed considerably above the level of the hillook.

With regard to the structure of the signals, piles or pikes of stone were found on the loftiest points of Water Crag, Shunnor Fell, and Great Whernside, marking the precise site of signals of the Ordnance Survey. On Settronside, a wellbuilt tower fifteen feet high and nine feet in diameter at the base, recently erected at a distance of forty-five yards to the north-east of the extreme summit of the fell, served as an excellent signal. On Lovely Seat there stands a lofty boundary pike situated some little below the level, but within a few yards of the highest point of the hill; to which point, in lieu of the base of the pike, on the measurement of the vertical angles the telescope was invariably directed. Stone towers about eight feet high, and nearly as much in diameter, marked the summits of High Fleak, Bakestone Edge, and Swarth Fell; the latter being erected on a large rock. The signals at Addlebrough and Rover Crag were of a similar description, but much inferior in dimensions. On the wall crossing the summit of Whitfield Hill were heaped, immediately over the most elevated point of ground, a number of loose stones; but this signal, from its insufficient dimensions, could seldom be distinctly seen through the telescope of the theodolite. The 
other signals consisted of conical piles about twelve feet in diameter at the base, and seven or eight feet high, constructed externally of huge sods, and filled up with loose peat-earth. There exists, however, this great objection to a turf-signal placed on a peat moor, - that the observer may not be able to distinguish it, at a remote station, from the peat stacks with which it is liable to be surrounded. For instance, although the pile of sods marking the most elevated point of the extensive and nearly level summit of Penhill, famous for its excellent turbaries, was placed on the northern extremity of an elevated cam (or mound) dividing Walden from Coverdale; yet so numerous were the heaps of peat raised from time to time to the west and north, that the signal, when observed from stations in those directions, could seldom be satisfactorily identified;-an uncertainty which has led to unusual discrepancies in the measurements of such of the distances as relate to that signal.

The horizontal angles were, with one exception*, measured by the six-inch theodolite, minutely described in Phil. Mag. and Annals, vol. iii. pp. 83-86. At Bear's Head, Shunnor Fell, BakestoneEdge, and Penhill, immediately on completing ore set of observations, the telescope was reversed in position within its Ys, and the observations, notwithstanding the consequent inconvenient position of the tangent screws, carefully repeated. From the unsettled state of the atmosphere, it would frequently occur that some of the distant hills had been obscured by mist or haze during the course of either the first or second set of observations, which rendered it necessary to apply to their readings the uncertain correction of half the mean difference of the two readings, registered for observations with the telescope in both positions. At Settronside, the summits of several of the fells were so rapidly shrouded in vapour that no time was afforded to reverse and re-adjust the telescope; but a few of the observations of most importance were repeated (by turning the screw situated under the parallel plates) on different parts of the divided circle.

It has been remarked, that the signals of the preceding survey, when observed from remote stations, although viewed under an angle considerably greater than that subtended by the fine vertical wire of the telescope, would totally disappear on interposing the latter; but the signals just described, from their superior magnitude, could be bisected in tolerably clear weather with the greatest ease and accuracy. On the occurrence, however, of haze in the atmosphere, the signal, suffi-

- The angle at Rover Crag between Harlen Fell and Penhill. 
ciently visible on entering the field of view of the telescope, became gradually more indistinct as it approached the wire, and wholly faded out of view at a distance from it of one or two minutes*.

Another annoying impediment to accurate bisection, the consequence of some defect in the tangent screw, or clamp, of the horizontal circles, requires to be noticed. Occasionally, on turning the screw in the proper direction to rectify an approximate bisection, the vertical wire of the telescope, after refusing for some time to obey its action, would be displaced in azimuth, not gradually, but at once, the quantity due to the degree of revolution of the screw.

In the registers of the measurement of the horizontal angles, there is given for every signal observed the mean of the various corresponding readings, reduced, when requisite, to the centre of the signal. At several of the stations some few of the more distant signals were never sufficiently clear for bisection; but the consequent blanks in the registers, marked $\mathrm{M}$, or $\mathrm{C}$, have been supplied, the former from the accurate data of Colonel Mudge, and the latter, by the following method, from the registers of the other stations. At $A$ the signals $\mathbf{C}$ and $\mathbf{D}$ were observed, but $\mathrm{B}$ conld not be seen. From the registers of $\mathbf{C}$ and $\mathrm{B}$ the angles $\mathrm{CBA}$ and $\mathrm{BCA}$ are extracted, and the angle $\mathrm{CAB}$. obtained by subtracting their

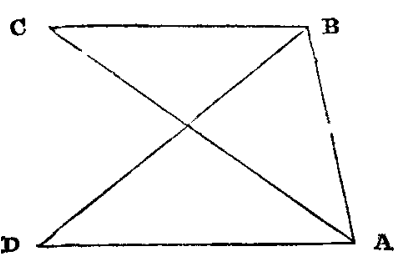
sum from $180^{\circ}$. Adding this angle to the reading for the signal $\mathrm{C}$, as given in the register of the observations made at $A$, (the graduations of the theodolite being numbered from left to right,) their sum is sub-

* I have lately had a telescope fitted up with two horizontal thick wires, to each of which is attached a delicate filament, both placed, as exhibited in the figure, in the same vertical line. In making an observation the telescope is moved until the signal appears to be equidistant from the horizontal wires, and as exactly bisected by an imaginary line connecting the two vertical filainents as the eye can estimate. In measuring vertical angles the telescope is to be half inverted within its $Y_{s,}$, and

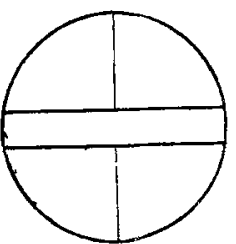
the filaments rendered truly horizontal.

Captain Kater and his associates experienced in hazy weather the same difficulty, or rather impossibility, of bisecting distant signals by the intersection of the (three) wires of their powerful telescope, but succeeded on making use of a minute particle of dust, fixed by Mr. Gardner, on the horizontal wire. (Phil. Trans. I828, p. 194). This method, it is to be doubted, would scarcely answer if applied to an ordinary telescope.

N.S. Vol.5. No. 29. May 1829. 
354 Mr. Nixon on the Measurement (by Trigonometry) of the

stituted in the register for an actual observation of the signal B. When A and B had been seen also from D (or any other station), two or more values of the required reading were procured by the same process of calculation, of which the mean was adopted.

When the distance between two signals $(E, A)$ has been measured from several bases ( $\mathrm{C}, \mathrm{B}, \mathrm{\& c}$.), the claim to accuracy of each measurement has been considered, in the determination of the proper mean, to be inversely as the greatest error to which, limiting the uncertainty of observation to one minute, it may be deemed liable.

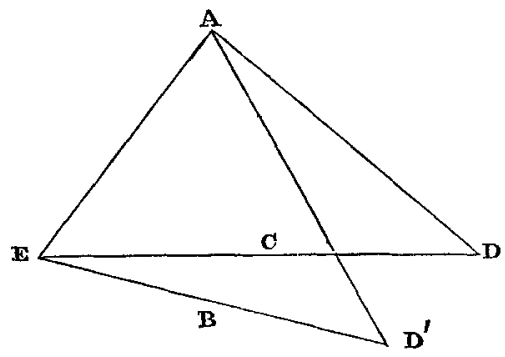
This maximum error of the distance in logarithms ( $x$ ) was calculated by the following formulæ, in which $d$ denotes the difference between the log. sine of the angle $D$, and that of the same angle $\pm 1^{\prime}$, and $a$ the corresponding difference for the angles $A$ and $\bar{A} \pm 1^{\prime}$.

CLass I.-Given the observed angles E, A, D, each corrected by one-third of the difference of their sum and $180^{\circ}$.

Case 1. $-\mathrm{D}$ and $\mathrm{A}$ being acute.

$x=d+a$, when $a=d$;

$x=\frac{2 d+4 a}{3}$, when $a$ exceeds $d$;

$x=\frac{4 d+2 a}{3}$, when $d$ exceeds $a$.

Case $2,-$ When either $\mathrm{D}$ or $\mathrm{A}$ is obtuse.

$$
\begin{aligned}
& x=\frac{2 d+2 a}{3}, \text { when } a=2 d, \text { or } d=2 a ; \\
& x=\frac{4 d-2 a}{3}, \text { when } d \text { exceeds } 2 a ; \\
& x=\frac{4 a-2 d}{3}, \text { when } a \text { exceeds } 2 d .
\end{aligned}
$$

Class II.-Given the observed angles $\mathbf{D}$ and $\mathbf{A}$ only. $x=a+d ; \mathrm{D}$ and $\mathrm{A}$ being both acute, or either of them obtuse.

Class III.-Given the observed angles $\mathrm{E}$ and $\mathrm{A}$ only. 
Heights of the principal Hills of Wensleydale, Yorkshire. 355

Case 1.-D and $\mathrm{A}$ being acute.

$$
x=a+2 d \text {. }
$$

Case 2.-When either $\mathbf{D}$ or $\mathbf{A}$ is obtuse.

$x=2 d-a$, when $d$ exceeds $a$;

$x=a$, when $a$ exceeds $d$.

Crass IV.-Given the observed angles D and E only.

Case 1.-D and $\mathrm{A}$ being acute.

$x=2 a+d$.

Case 2.-When either $\mathbf{D}$ or $\mathbf{A}$ is obtuse.

$x=2 a-d$, when $a$ exceeds $d ;$

$x=d$, when $d$ exceeds $a$.

It is almost superfluous to remark, that the logarithmic differences are treated in the notation as common numbers.

The following list contains for every triangle of which all the angles have been observed, the difference of their sum and $180^{\circ}$.

\begin{tabular}{|c|c|c|c|c|c|}
\hline$\left.-0^{\prime}\right]^{\prime \prime}$ & $-0^{\prime} 28^{\prime \prime}$ & $-0^{\prime} 41^{\prime \prime}$ & $-\mathbf{1}^{\prime} \quad 4$ & $-2^{\prime} \quad 6^{\prime \prime}$ & $+0^{\prime} 42^{\prime \prime}$ \\
\hline 04 & 029 & 042 & 16 & +014 & 044 \\
\hline 013 & 030 & 042 & 110 & 021 & $0 \quad 58$ \\
\hline 014 & 0.30 & 047 & 125 & 021 & 129 \\
\hline $\begin{array}{ll}0 & 17\end{array}$ & 035 & 055 & 127 & o 31 & 129 \\
\hline 027 & $\begin{array}{ll}0 & 39\end{array}$ & 12 & 128 & 031 & \\
\hline
\end{tabular}

Mean error $45^{\prime \prime}$, or $15^{\prime \prime}$ per angle.

Registers of the Measurement of the Horizontal Angles.

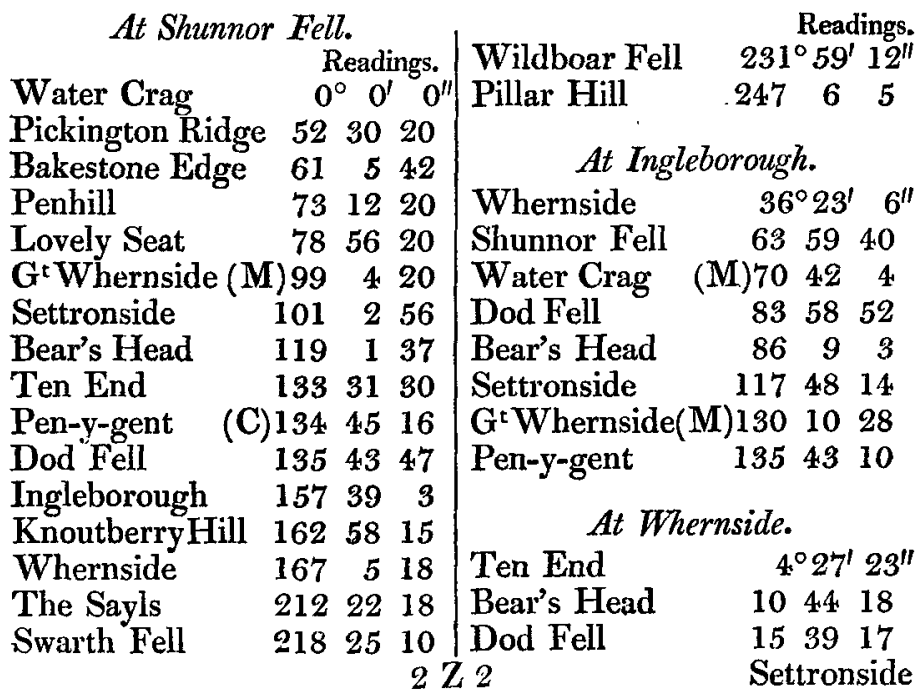


$356 \mathrm{Mr}$. Nixon on the Measurement (by Trigonometry) of the

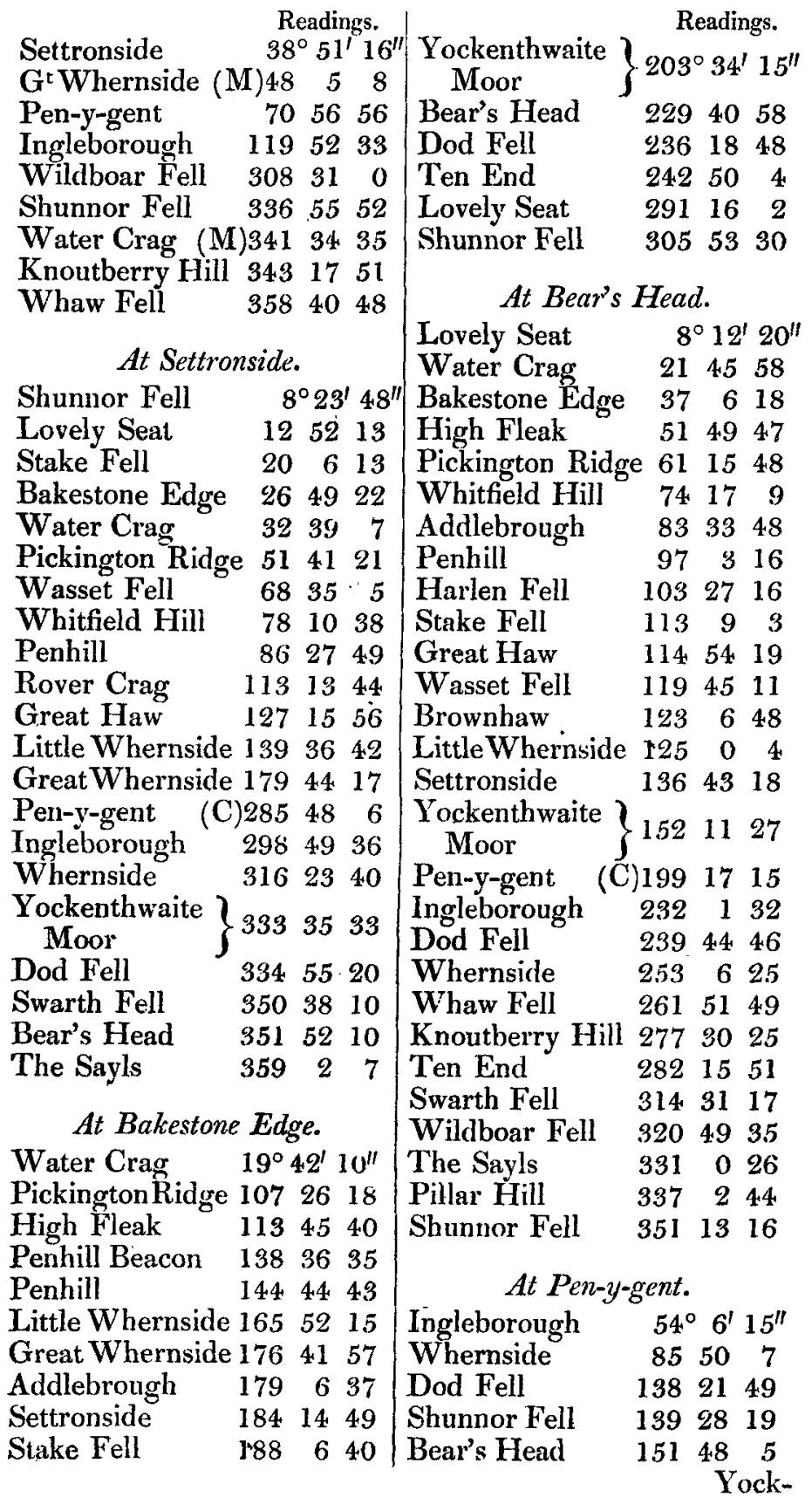


Heights of the principal Hills of Wensleydale, Yorkshire. 357

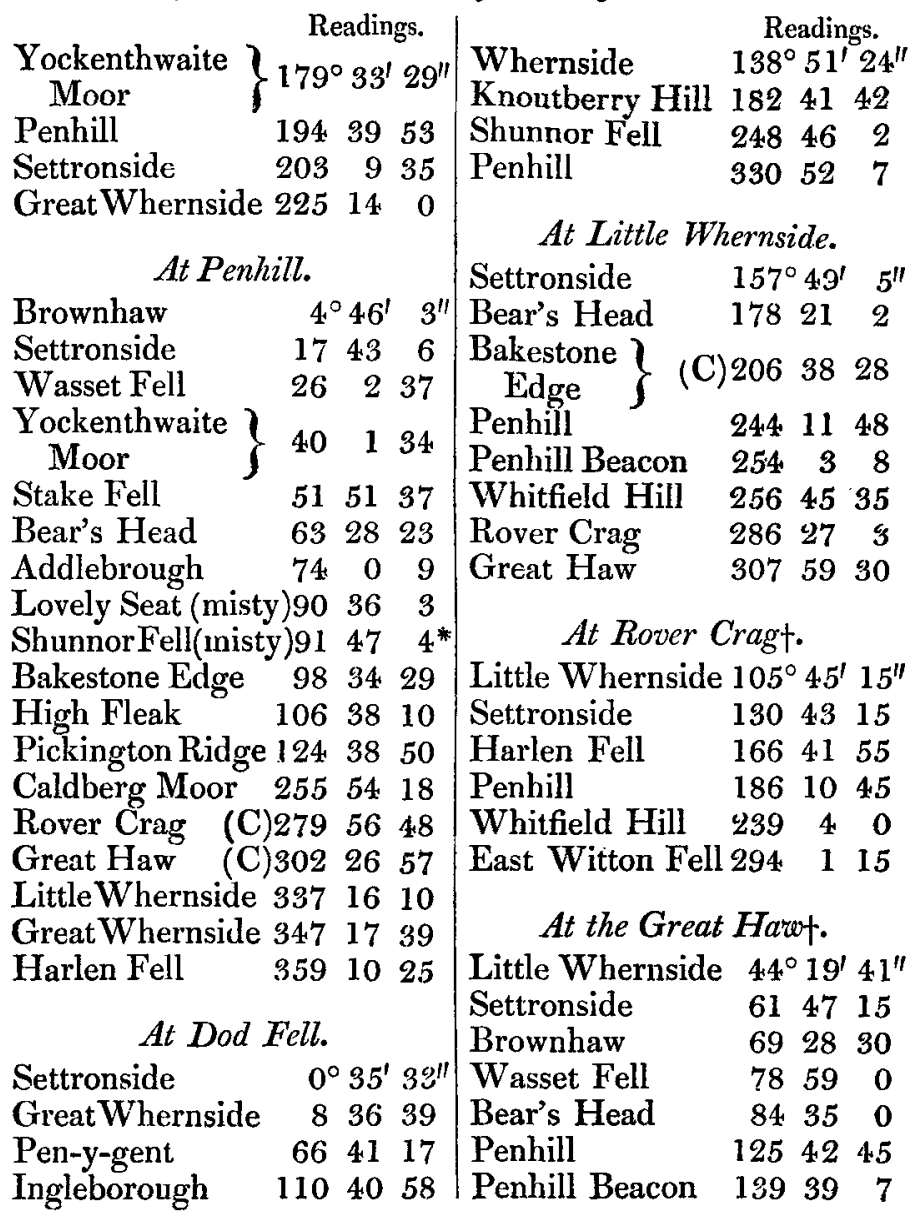

Calculation of the mean Distances.

Bases from the Ordnance Survey. Feet.

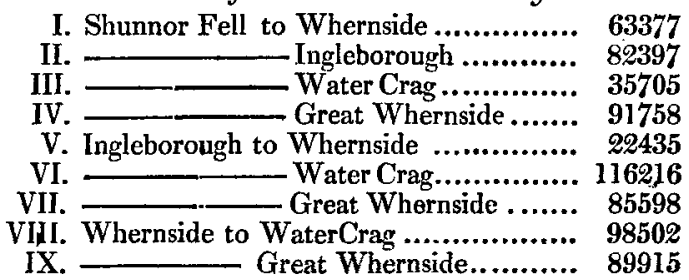

* Rejected in the calculation of the distance from Shunnor Fell to Penhill. + At Rover Crag and Great Haw the theodolite was placed exactly over the centre of the signal. 
Shunnor Fell to Settronside.

By Shunnor Fell and Whernside 70957

Ingleborough 70965 Water Crag 70931 Mean $\overline{70953}$

Water Crag to Settronside.

By Water Crag and Shunnor Fell 85304

$\longrightarrow$ Ingleborough 85327 Whernside 85313

$$
\text { Mean } \overline{85315}
$$

Whernside to Settronside.

By Whernside and Shunnor Fell 73489

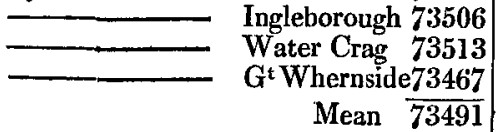

Ingleborough to Settronside.

By Ingleborough and Shunnor Fell 73410 Whernside 73428 Water Crag 73414 G'Whernside73409 Mean 73411

Shunnor Fell to Bear's Head.

By Shunnor Fell andIngleborough 35613 Whernside 35625 Water Crag 35581 Settronside 35632 Mean $\overline{\mathbf{3 5 6 1 7}}$

Water Crag to Bear's Head.

By Water Crag and Ingleborough 63502 Whernside 61467 $\begin{array}{ll}\text { Shunnor Fell } 61430 \\ - & \text { Settronside } 61466\end{array}$

Whernside to Bear's Head.

By Whernside and Ingleborough 47609

$\longrightarrow$ Shunnor Fell 47626

$\longrightarrow$ Water Crag 47619

Settronside 47621 Mean $\overline{47619}$

Ingleborough to Bear's Head.

By Ingleborough and Whernside 58910 Shunnor Fell 58933 Water Crag 58950 Settronside 58914 Mean $\overline{58923}$
Settronside to Bear's Head. Feet. By Settronside and Ingleborough 38690 Whernside 38672 Water Crag 38667 Shunnor Fell 38659 Mean $\overline{\mathbf{3 8 6 7 6}}$

Shunnor Fell to Bakeston Edge.

By Shunnor Fell and Water Crag 26333 $G^{\mathrm{t}}$ Whernside26291 Settronside 26330 Bear's Head 26327 Mean $\overline{26326}$

Water Crag to Bakestone Edge.

By Water Crag and Shunnor Fell 32548 - Bear's Head 32536

Mean $\overline{32543}$

Great Whernside to Bakestone Edge.

By GtWhernside and ShunnorFell7 2853

Settronside to Bakestone Edge.

By Settronside and Shunnor Fell 53508

Bear's Head 53524

Mean $\overline{\mathbf{5 3 5 1 7}}$

Bear's Head to Bakestone Edge.

By Bear's Head and Shunnor Fell 31077

Water Crag 31090

Settronside 31100

Mean $\overline{31084}$

Shunnor Fell to Pen-y-gent.

By Shunnor Fell and Ingleborough 78500 Whernside 78505

$G^{t}$ Whernside78499

Mean $\overline{78502}$

Ingleborough to Pen-y-gent.

By Ingleborough and ShunnorFell 32168

Whernside 32157

Bear's Head 32154

Mean $\overline{\mathbf{3 2 1 6 0}}$

Whernside to Pen-y-gent.

By Whernside and Shunnor Fell 42097

$\mathrm{G}^{\mathrm{t}}$ Whernside 42094

Ingleborough 42090

Bear's Head 42085

Mean $\overline{42092}$

Great 
Heights of the principal Hills of Wensleydale, Yorkshire. 359

Great Whernside to Pen-y-gent. Feet. By G' Whernside and ShunnorFell53668 Whernside 53680 Mean $\overline{5367 \overline{6}}$

Bear's Head to Pen-y-gent.

By Bear's Head and Ingleborough 45258 Whernside 45250 Mean $\overline{45254}$

Settronside to Pen-y-gent.

By Pen-y-gent and $G^{t}$ Whernside 43933 Shunnor Fell 43933 Bear's Head 43944 Whernside 43944 Mean $\overline{\mathbf{4 3 9 3 8}}$

Great Whernside to Settronside. By $\mathrm{G}^{\mathrm{t}}$ Whernside and Whernside 21015 Ingleborough20985 Pen-y-gent 20991 Mean $\overline{20993}$

Shunnor Fell to Dod Fell.

By Shunnor Fell andG ${ }^{\text {t Whernside42182 }}$ Whernside 42167 Ingleborough 42166 Settronside 42166 Bear's Head 42163 Mean $\overline{42168}$

Ingleborough to Dod Fell.

By Ingleborough and ShunnorFell 46055 Settronside 46048 Pen-y-gent 46068 Whernside 46068

Mean $\overline{46060}$

Whernside to Dod Fell. By Whernside and Shunnor Fell 35083 Settronside 35087 - - Ingleborough 35095 Pen-y-gent 35096 Mean $\overline{\mathbf{3 5 0 9 0}}$

Pen-y-gent to Dod Fell.

By Pen-y-gent and $G^{t}$ Whernside 36326

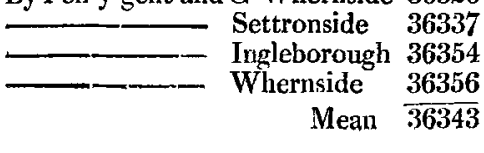

Bear's Head to Dod Fell.

Feet. By Bear's Head and Settronside 13014 Shunnor Fell 13022

Mean $\overline{\mathbf{1 3 0 1 8}}$

Settronside to Dod Fell.

By Settronsideand Ingleborough 43506

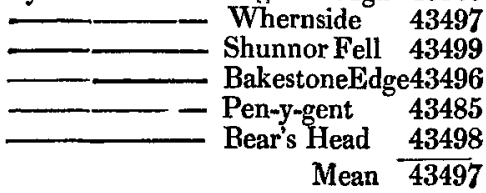

Bakestone Edge to Dod Fell.

ByBakestoneEdge andSettronside49398

Great Whernside to Dod Fell.

By G'Whernsideand ShunnorFell63159

Pen-y-gent 63148

Mean $\overline{63154}$

Shunnor Fell to Penhill.

ByShunnor Fell andPen-y-gent $\quad 72176$

Bear's Head 72171

Settronside 72185

Dod Fell 72148

Mean $\overline{72170}$

Bear's Head to Pentill.

By Bear's Head and Shunnor Fell 53800

Settronside 53821

BakestoneEd.33841

Pen-y-gent 53800

Mean $\overline{53816}$

Bakestone Edge to Penhill.

By Bakestone Edgeand Settronsi. 46773

$G^{\mathrm{t}}$ Whernside 46797

Mean $\overline{\mathbf{4 6 7 8 6}}$

Pen-y-gent to Penhill.

By Pen-y-gent and ShunnorFell 77287

Dod Fell 77320

Bear's Head 77292

Mean $\overline{77300}$

Dod Fell to Penhill.

By Dod Fell and Shunnor Fell $\quad 64623$ Settronside

64660

Pen-y-gent

64660

Mean $\overline{64648}$

Great 
Great Whernside to Penhill. Feet. By $\mathrm{G}^{\mathrm{t}}$ Whernside and Settronside 41388

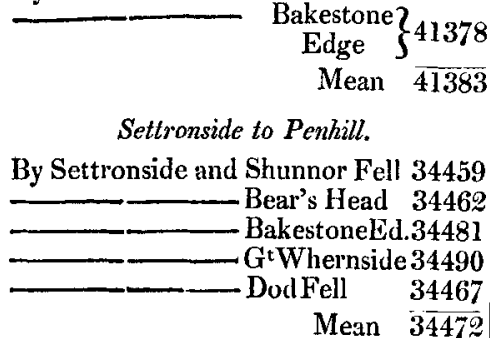

Bear's Head.to Little Whernside.

ByBear'sHead andBakestoneEdge58851

- Penhill 58850 - Settronside Mean $\overline{58849}$

Penkill to Little Whernside. By Penhill and Bear's Head Settronside - Bakestone Eige 27656

27642 27642 Mean $2 \overline{7647}$

Baliestone Edge to Little Whemside. By Bakestone Edge \& Bear's Head 65539 Settronside 65540 $\longrightarrow \underset{\text { Mean }}{\text { Penhill }}-\frac{65562}{65547}$ Settronside to Little Whernside. By Settronside and Bear's Head 22402 - BakestoneEd.22412 Penhill 22413 Mean $\overline{22409}$

Bear's Head to Great Haw.

By' Bear's Head and Settronside 70107

$$
\begin{array}{cc}
\text { Mean } & \frac{70117}{70112} \\
\text { Penhill to Great Haw. } & \\
\text { By Penhill and Bear's Head } & \mathbf{2 5 0 8 0} \\
\hline \text { Settronside } & \mathbf{2 5 0 7 8} \\
\text { Mean } & \overline{25079} \\
\text { Settronside to Great Haw. } \\
\text { By Settronside and Bear's Head } & 37098 \\
\hline \text { Menhill } & \mathbf{3 7 1 1 7} \\
\text { Mean } & \mathbf{3 7 1 1 5}
\end{array}
$$

\section{Mean}

Great Haw to Little Whernside. Feet. By Little Whernside and Penhill 15966 - Peruhill to Great Haw 15961

Mean $\overline{15964}$

Penhill to Rover Crag.

By Penhill and Settronside 18846 Little Whernside 18853

Mean $\overline{\mathbf{1 8 8 5 0}}$

Settronside to Rover Crag.

By Settronside and Penhill 41465

Lit.Whernside41460

Mean $\overline{41463}$

Little Whernside to Rover Crag.

By Lit.Whernside and Penhill $\quad 23600$ - Settrcnside 23591

Mean $\overline{\overline{23596}}$

Rover Crag to Caldberg Moor.

By Rover Crag and Penhill $\quad 10315$

Penhill to Caldberg Moor.

By Rover Crag and Penhill 24101

Settronside to Caldberg Moor.

By Rover Crag and Penhill 51430

Penhill to Harlen Fell.

By Penhill and Rover Crag $\quad \mathbf{6 3 6 0}$

Mean $\overline{6358}$

Bear's Head to Harlen.

By Bear's Head and Penhill

$\mathbf{5 1 3 8 0}$

Rover Crag to Harlen.

By Rover Crag and Penhill

18734

Bear's Head to Wasset Fell.

By Bear's Head and Settronside 37719

\begin{tabular}{rr} 
Mean & $\overline{\mathbf{3 7 7 2 0}}$ \\
Penhill to Wasset Fell. & \\
By Penhill and Bear's Head & $\mathbf{2 3 9 4 8}$ \\
Great Haw & $\mathbf{2 3 9 5 2}$ \\
Mean & $\overline{23950}$ \\
Settronside to Wasset Fcll. \\
By Settronside and Great Haw & 11315 \\
\hline Bear's Head & $1131: 2$ \\
Mean & $\begin{array}{c}11314 \\
\text { Bear's }\end{array}$
\end{tabular}


Bear's Head to Brownhaw. By Bear's Head and Penhill Great Haw Mean

Penhill to Brownhaw.

By Penhill and Bear's Head Great Haw

Mean $\overline{\mathbf{2 3 7 3 8}}$

Iittle Whernside to Penhill Beacon.

By Little Whernside \& Bakestone Edge

31131

$\longrightarrow$ Great Haw 31100

Mean $\overline{\mathbf{3} 1115}$

Bakestone Edge to Penhill Beacon.

By Bakestone Edge and Little ?

Whernside 50038

Great Whernside to Penhill Beacon. By calculation 46592

Bear's Head to Whitfield Hill. By Bear's Head and Settronside 74385 Lit.Whernside74311 Mean $\overline{\mathbf{7 4 3 3 7}}$

Settronside to Whitfield Hill.

By Settronside and Bear's Head 66079 Rover Crag Mean $\overline{66034}$

Shunnor Fell to Pickington Ridge.

By Shunnor Fell and Settronside 48679 는 Bear's Head 48692 Penhill 48678 Mean $\overline{48683}$

Bakestone Edge to Pickington Ridge. ByBakestoneEdgeandSettronside2\%980 -Bear'sHead22990 Penhill 23001 Mean $\overline{22990}$

Bear's Head to Pickington Ridge.

By Bear's Head and Settronside 47513

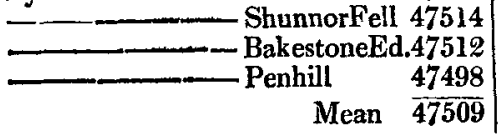

N.S. Vol. 5. No. 29. May 1829.
Penhill to Pickington Ridge. Feet. By Penhill and Settronside $\quad 31725$ Shunnor Fell $\quad 31709$ 31707 31719 $\overline{31715}$

Settronside to Yockenthwaite Moor.

By Settronside and Pen.y-gent 18562 Bear's Head ' 18570 BakestoneEdge18563 Penhill 18563 Mean $\overline{\mathbf{1 8 5 6 4}}$

Bear's Head to Yockenthwaite Moor. By Bear's Head and Settronside 21834

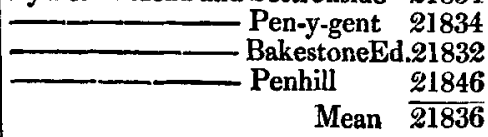

Bakestone E'dge to Yockenthwaite Moor. ByBakestoneEdgeandSettronside44937 Bear'sHead44926 Penhill 44945 Mean $\overline{\mathbf{4 4 9 3 6}}$

Penhill to Yockenthwaite Moor.

By Penhill and Settronside $\quad 45059$ - Bear's Head $\quad 45048$ Bakestune Edge 45078 Mean $\overline{45062}$

Settronside to Stake Fell.

By Settronside and Bear's Head 19679 Penhill 19677 Mean $\overline{\mathbf{1 9 6 7 8}}$

Bear's Head to Stake Fell.

By Bear's Head and Settronside 23281 BakestoneEd.23279 Mean $\overline{\mathbf{2 3 2 8 0}}$

Penhill to Stake Fell.

By Penhill and Settronside $\quad 32117$ Bakestone Edge 32126 Mean $\overline{32122}$

Bakestone Edge to Stake Fell. By BakestoneEdge \& Bear's Head 34046 - Penhill $\mathbf{3 4 0 5 8}$ Mean $\overline{\mathbf{3 4 0 5 2}}$ 3 A Bear's 
Bear's Head to Addlebrough. Feet. Bear's Head to Knoutberry Hill. Feet. By Bear's Head \& BakestoneEdge 24192 By Bear's Head and Shunnor Fell 27905* By Bear's Head 24159 Mean $\overline{24175}$

Penhill to Addlebrough.

By Penhill and Bakestone Edge 30836 Bear's Head 30843 Mean $\overline{\mathbf{3 0 8 4 0}}$

Bakestone Edge to Ten End.

By BakestoneEdge \& ShunnorFell35800

- Bear's Head 35793 Mean $\overline{\mathbf{3 5 7 9 7}}$

Bear's Head to Ten End.

By Bear's Head and Shunnor Fell 8975 BakestoneEdge8974

Shunnor Fell to Pillar Hill.

By Shunnor Fell and Bear's Head 14247

Bear's Head to Pillar Hill.

By Shunnor Fell and Bear's Head 45798

Shunnor Fell to the Sayls.

By Shunnor Fell and Bear's Head 13426

Settronside 13420

Mean $\overline{13423}$

Bear's Head to the'Sayls.

By Bear's Head and Shunnor Fell38790

Shunnor Fell to Wildboar Fell.

By Shunnor Fell and Whernside 30208

Bear's Head 30192

Bear's Head to Wildboar Fell.

Mean $\overline{\mathbf{3 0 2 0 0}}$

By Bear's Head and Whernside $\mathbf{5 4 9 5 1}$ Shunnor Fell 54946

Shunnor Fell to Swarth Fell.

By Shunnor Fell and Bear's Head 30693

Mean $\overline{\mathbf{5 4 9 4 8}}$

Settronside 30679 Mean $\overline{30686}$

Bear's Head to Swarth Fell.

By Shunnor Fell and Bear's Head 50670

Great Whernside to Swarth Fell.

By calculation . .110096

[To be continued.]

Shunnor Fell to Knoutberry Hill.

By Bear's Head and Shunnor Fell38598*

Great Whernside to Knoutberry Hill.

By calculation .................... 82426

Bear's Head to Whaw Fell.

By Bear's Head and Whernside 27993*

Shunnor Fell to Lovely Seat.

By Shunnor Fell and Bear's Head 12396

BakestoneEd.12382

Mean $\overline{12390}$

Bakestone Edge to Lovely Seat.

By BakestoneEdge and Shun- ?

nor Fell .......... 15027

Bear's Head 15023

Settronside 15050

Meàn $\overline{15033}$

Penhill to Lovely Seat.

By Penhill and Settronside $\quad 59875$

Mean $\overline{\mathbf{5 9 8 6 3}}$

Settronside to Lovely Seat.

By Settronside and Penhill 59652 Bakestone Edge 59683

Mean $\overline{59667}$

Bear's Head to Lovely Seat.

By Bear'sHead and ShunnorFell 27326

\begin{tabular}{cr}
- BakestoneEdge 27340 \\
\hline Penhill & $\frac{27296}{\text { Mean }}$ \\
\hline 27321 \\
Penhill to High Fleak.
\end{tabular}

By Penhill and Bear's Head 38218

38235

Mean $\overline{38 \overline{226}}$

Bear's Head to High Fleak.

By Bear's Head \& BakestoneEdge 36846

Penhill $\frac{36329}{36838}$
Mean $\overline{36}$

Bakestone Edge to High Fleak.

By BakestoneEdge \& Bear's Head 10413

Penhill 10415

Mean $\overline{\mathbf{1 0 4 1 4}}$

* See Phil. Mag. and Annals, vol. iii. pages 94, 95.

LIII. On 